\title{
COVID-19: the impact of a global crisis on sustainable development research
}

\author{
Walter Leal Filho ${ }^{1,2} \cdot$ Anabela Marisa Azul ${ }^{3} \cdot$ Tony Wall $^{4,5} \cdot$ Claudio R. P. Vasconcelos ${ }^{6,7} \cdot$ Amanda Lange Salvia $^{8}$. \\ Arminda do Paço ${ }^{9} \cdot$ Kalterina Shulla $^{10}$. Vanessa Levesque ${ }^{11}$. Federica Doni ${ }^{12}$. Lorena Alvarez-Castañón $^{13}$. \\ Claudia Mac-lean ${ }^{14}$. Lucas Veiga Avila ${ }^{15}$. Luana Inês Damke ${ }^{16}$. Paula Castro ${ }^{17}$. Ulisses M. Azeiteiro ${ }^{18}$. \\ Bárbara Fritzen $^{8}$ (1) Paula Ferreira ${ }^{19} \cdot$ Fernanda Frankenberger ${ }^{20,21}$
}

Received: 29 June 2020 / Accepted: 11 September 2020 / Published online: 9 November 2020

(c) Springer Japan KK, part of Springer Nature 2020

\begin{abstract}
The crisis caused by COVID-19 has affected research in a variety of ways. As far as research on sustainable development is concerned, the lockdown has significantly disrupted the usual communication channels and, among other things, has led to the cancellation of meetings and long-planned events. It has also led to delay in the delivery of research projects. There is a gap in the literature in regards to how a global crisis influences sustainability research. Therefore, this ground-breaking paper undertakes an analysis of the extent to which COVID-19 as a whole, and the lockdown in particular, has influenced sustainability research, and it outlines the solutions pursued by researchers around the world to overcome the many challenges they have experienced. This paper also outlines some measures that may be implemented in the future to take more advantage of existing technologies that support research on sustainable development.
\end{abstract}

Keywords COVID-19 $\cdot$ Sustainability $\cdot$ Research $\cdot$ Crisis

\section{Introduction}

The global health crisis caused by COVID-19 impacted research activities undertaken by higher education institutions, research centres and research groups in a variety of ways. Despite significant efforts to decrease the effects of the pandemic crisis, some researchers around the world have been (or are) forced into social isolation, and they had to interrupt face to face meetings with their colleagues, which had an adverse effect on the work within research teams. Furthermore, during the peak of the pandemic, several activities in research laboratories were interrupted. This has led to delays in the scheduling of many research projects. In

Handled by Yuto Kitamura, The University of Tokyo Graduate School of Education, Japan.

Electronic supplementary material The online version of this article (https://doi.org/10.1007/s11625-020-00866-y) contains supplementary material, which is available to authorized users.

Bárbara Fritzen

barbaramaria.fritzengomes@haw-hamburg.de many cases, researchers were forced to apply for an extension of the deadlines for their activities.

Research centres are redesigning and adjusting their research policies to try to respond to their partnerships and stakeholders while trying to maintain the strongest local impact (McKinsey \& Company 2020). Particularly, research on Sustainable Development (SD) encompasses more critical issues than other fields of research. From different approaches and disciplines, sustainability research has been characterised as facing the multidimensional challenges of the complex relationship between the environment, the economy and society's prosperity. Thus, the spread of COVID-19 is upsetting climate and biodiversity meetings around the world. 'Coronavirus hits a critical year for nature, climate' (Uwaegbulam 2020) disrupting 'UN Meeting Plans Around the World' (Leone 2020). Several meetings planned for 2020 were postponed, rescheduled or virtualized, such as the SDG Planning Calendar, IPBES meetings, IUCN, UNFCCC and the UN Ocean Conference (UN 2020a, b; UNFCCC 2020).

This response to COVID-19 negatively distresses the potential establishment of a treaty on a new global framework to limit warning and to protect marine and land biodiversity over the next decade. In spite of the coronavirus 
crisis, there are increasing research outputs regarding SARSCoV-2 and COVID-19. The European Commission plays a crucial role in supporting research and innovation by coordinating European and global research efforts, including preparedness for pandemics. The Commission is launching several special actions in 2020 that address epidemiology, the development of diagnostics, vaccines, as well as the infrastructures needed for this research (EU 2020).

Apart from research on the virus (Yan et al. 2020; Shang et al. 2020a; among others) and vaccines (Amanat and Krammer 2020; Shang et al. 2020b; among others), the interfaces between nature, biodiversity, viruses and zoonotic diseases/zoonotic viruses (Johnson et al. 2020; Lam et al. 2020; Salata et al. 2019; Zhou et al. 2020c; Xu 2020) are highlighted, and reservoirs and interspecies transmission viruses (Chan et al. 2013) should be further discussed in relation to sustainability. On the basis of this consideration, WWF Italy published a document on pandemics and their related effects on the destruction of ecosystems (WWF 2020).

Evidence demonstrated that most of the so-called emerging diseases, such as Ebola, AIDS, SARS, swine flu and the new coronavirus, are not random catastrophes but the consequence of our impact on natural ecosystems. Human activity has significantly altered three quarters of the emerged land surface and two-thirds of the oceans, and it has determined the birth of a new era called the 'Anthropocene' (WWF 2020). Wealth and the abundance of species, two important components of biodiversity, can counteract the spread of diseases in several ways. Among these, the dilution effect and the coevolution effect should be analysed and discussed (WWF 2020).

Another relevant aspect is the reduction of pollution and carbon emissions during this period of lockdown. Some organisations, at the local and international levels, are checking the current benefits from the shutdown of factories and business activities. For instance, the European Environment Agency (EEA) is assessing how coronavirus measures have influenced the concentrations of air pollution by developing a viewer that tracks the weekly average concentrations of nitrogen dioxide $\left(\mathrm{NO}_{2}\right)$ and particular matter $\left(\mathrm{PM}_{10}\right.$ and $\mathrm{PM}_{2.5}$ ). The drop-in air pollution should be investigated in view of forward-looking investments and ambitious policies to move towards a resilient and sustainable society (EEA 2020).

A common axiom in sustainability research is the intersection between complex networks of interactions and the cultural, territorial, organisational, institutional, and infrastructural aspects (Leahey and Barringer 2020; Waas et al. 2010). This has motivated the transition from sustainability to participatory and transdisciplinary research approaches to accelerate their impacts and magnify them in the long term or to succeed in problem-focused research (Williams and Robinson 2020; Rau et al. 2018). Transnational collaborations can support effective progress in sustainability research. Caniglia et al. (2017) reported some successful factors such as "combining local and global considerations; making effective use of digital technologies; capitalizing on cultural and national differences; and making the best of available resources' (Caniglia et al. 2017, p. 764).

Transdisciplinary research models have been proposed as routes that use science to solve complex socio-environmental problems, despite the implied disciplinary tensions (Klenk and Meehan 2017). Particularly, in view of the implementation of the Sustainable Development Goals (SDGs), sustainable research requires integrative science and the active involvement of academic institutions and non-academic actors, such as innovative companies, municipalities and civil society, namely as a living lab (Bergvall-Kåreborn and Ståhlbröst 2009; Schneidewind 2014; Wiek et al. 2014). To ensure the effectiveness of such research and its societal consequences, a transition to participatory sustainability approaches may be a successful solution.

Based on this framework, the crisis caused by COVID-19 has posed new challenges for sustainability research, and it is relevant to study how a global crisis influences such research. The socio-political measures taken under high uncertainty to contain its spread have been absolutely essential (Fong et al. 2020; Zhou et al. 2020a). Beyond the significant interruptions of the usual communication channels or the delays in the delivery of research projects findings, these measures equally represent a high uncertainty for sustainability research. Ivanov (2020) shows that new research tensions are surfacing in regards to the impact of COVID-19 with variables that hinder them; the pandemic is a special disruption risk that begins with a limited scope on a large scale, and spreads across many geographic regions.

According to Angeloni (2020), a large part of recent research has focused on the impact of technological progress and globalisation to achieve sustainability. However, there is a latent demand for new ways of doing sustainability research to achieve transdisciplinarity and blur the geographic and communication boundaries that inhibit research processes. The literature reports some alternatives with potential in sustainability research in times of epidemic outbreaks; digital technologies such as data analysis, artificial intelligence, machine learning or digital twins (Ivanov 2020), Big Data technologies in geographic information systems (Zhou et al. 2020a), or drones, 5G and robotics (Show et al. 2020) are some of them. Beier et al. (2020) explain that these technologies have a significant influence on the alignment of the objectives of sustainable development.

These alternatives for sustainability research open a relevant research area. According to Zhou et al. (2020a), the main challenge is to determine the strategies that have the appropriate mixtures of traditional methods and new 
technologies to impact sustainability. Besides, Show et al. (2020) state that it is essential to consider that the extensive use of emerging technologies goes beyond a pandemic response; it is necessary to appropriately link technology to the socioeconomic and scientific context. Therefore, this article analyses to what extent COVID-19 as a whole and the blockade in particular have influenced sustainability research, and it describes the action paths that researchers around the world identify for overcoming the experienced challenges and the measures that can be implemented in the future based on existing technologies.

The remainder of this paper is structured as follows: Section 2 presents COVID-19, related facts and figures and its impact on research, with a specific focus on sustainable development. Section 3 discusses the methodological aspects by describing the questionnaire delivered via a sophisticated on-line survey. The findings are discussed in Sect. 4, and Sect. 5 makes some final remarks about further development and practical implications of this research.

\section{COVID-19: facts, figures and impacts on sustainability research}

A new pathogen, identified as a different coronavirus (SARS-CoV-2), caused an unusual pneumonia (COVID19) outbreak in December 2019, starting in Wuhan city in Hubei (a central province in China) (Zhou et al. 2020b) and spreading rapidly in the first three months of 2020 to 201 other countries and territories (La et al. 2020). This pathogen is a beta coronavirus and shares a genetic sequence and viral structure with severe respiratory syndrome coronavirus (Zhou et al. 2020b). The alignment of the genome sequence of the COVID-19 virus revealed that the closest relationship was with the SARS-like bat coronavirus (WHO 2020a).

According to the World Health Organization (WHO 2020a), COVID-19 is transmitted mainly via droplets and fomites during close, unprotected contact with an infector. Regarding symptoms, the disease presentation can range from no symptoms (asymptomatic) to severe pneumonia and death. The fast contagion and severity of this new disease has driven the WHO to change its statement from classifying the outbreak as a 'Public Health Emergency of International Concern' on the 30th of January, 2020 to a 'Pandemic' on the 11th of March, 2020 (WHO 2020b).

From the first Situation Report of Coronavirus disease 2019 (COVID-19) on the 21 st of January 2020, there were 282 confirmed cases from four countries, including China (278), Thailand (2), Japan (1) and the Republic of Korea (1). Of the confirmed cases, 51 cases were severely ill, 12 were in critical conditions, and 6 were death. The cases in Thailand, Japan and the Republic of Korea were exported from Wuhan (WHO 2020c). On the 8th of February, the scenario was completely different: the Novel Coronavirus (2019-nCoV) Situation Report mentioned a total case count of 34,886 confirmed (3419 new) with 86 new deaths in China. Outside of China, there were 288 confirmed (18 new) in 24 countries and 1 death. The WHO risk assessment in China was very high at the regional level and high at the global level (WHO 2020d). The following month, the Situation Report of the 8th of March (WHO 2020d) reported a total of 105,586 confirmed cases. In China, there were 80,859 confirmed cases and 3,100 deaths; outside of China there were 24,727 confirmed and 484 deaths in 101 countries. The WHO risk assessment both in China and globally was very high (WHO 2020e). After a month, the Situation Report of the 8th of April presented a total of 1,353,361 confirmed cases spread throughout the European, Americas, Western Pacific, Eastern Mediterranean, and South-East Asia regions. At this point, the risk assessment at the global level was very high (WHO 2020f).

Given the urgency of this outbreak, the international academic community is mobilising ways to accelerate the development of disease detection and intervention ( $\mathrm{La}$ et al. 2020). Schools, universities, and research institutions are temporarily closed around the world in order to slow the spread of the COVID-19 pandemic, impacting over $91 \%$ of the world's students (UNESCO 2020). The closure of higher education institutions (HEI) affects not only the students at these schools but also the faculty who normally conduct research (Wang et al. 2020).

This paper focuses specifically on the effect of COVID19 closures on sustainable development research. The UN Secretary General had considered 2020 as a 'super year' for sustainability action, prior to the COVID-19 outbreak (Djalante et al. 2020). Sustainability efforts are supported by research that explores environmental, social and economic dimensions of complex problems. This research is often collaborative, involving university researchers and non-academic stakeholders, with the goal of advancing sustainable development goals in specific places (van Kerkhoff and Lebel 2006).

The lockdown that has occurred in many countries can influence current work of researchers through work place restrictions, movement constraints for accessing research sites, facilities constraints, interruption of social and political processes in which research is situated, access to physical libraries or to high-speed internet, lack of peer support, and work-family interface challenges, among others. Furthermore, the increased uncertainty amongst the population, accompanied by stress, actual sickness, and mental health challenges, can influence researchers as well.

While there are many potential impacts of the COVID19 closures on research, very little has been documented in published literature. It has been reported that the closures have influenced the biomedical scientists who rely on wet 
labs (Nature Medicine 2020). There are also news stories of impacts on sustainability research. For example, the Smithsonian Magazine has reported that the Northern Gulf of Alaska Long Term Ecological Research Project may halt the three research cruises planned for 2020, interrupting the physical and biological data that has been collected for decades to understand oceanographic trends in this region (Pope 2020). Similarly, they report that a professor of engineering at a US-based college has delayed a community-based collaborative research project in Greenland for creating sustainable energy solutions, relying instead on internet-based communications to gather preliminary data (Pope 2020). Lab experiments may also be impacted, which is especially troubling for researchers that must keep plants and animals alive during strict laboratory closures (Kimbrough 2020).

Data collection procedures and actual fieldwork for surveys for research projects had to be adapted, in particular if targeting the elderly population (Scherpenzeel et al. 2020). Also, Sastry et al. (2020) and Gummer et al. (2020) showed that COVID-19 had a negative effect on fieldwork. This included the reduction of survey response rates and the termination of home visits or face-to-face interviews that can represent an important component of studies, including the ones that address the social dimension of sustainable development.

For sustainability research, the exchanging events, forums and open communication arenas are of particular importance. International conferences, due to their interdisciplinary character and diverse stakeholder's participation, are used by higher educational institutions as a means to promote sustainability (Berchin et al. 2018). Around the world, many such events are cancelled or postponed, impacting the exchange of knowledge, ideas, approaches, and further international collaborations.

An adaptation of sustainability research themes or change of the research's trajectories can also be expected. Knowledge from social scientific research related to the contextual behaviour aspects of communities, for instance, can be aligned with biomedical insights of the epidemic (La et al. 2020). Similarly, the provision of knowledge and science in understanding disaster and health-related emergency risks, as part of the sustainability research on current strategies for disaster resilience as outlined in the SENDAI Framework, can contribute to responses to COVID-19 (Djalante et al. 2020). Emergency research can be a response for the risk management of newly created situations at Chinese universities (Wang et al. 2020).

Constraints in doing sustainability research can be exacerbated by institutional capacity to change (Spoelstra 2013). The degree to which COVID-19 will have lasting impacts on sustainability science research is unclear; disasters tend to facilitate societal change (Cohen 2020). It is likely that the global health crises, with their associated environmental, social and economic aspects, will continue in the future, and it is important that scientific institutions develop methods for dealing with the associated uncertainties in order to continue to provide context-specific knowledge to aid in decision making (Djalante et al. 2020).

\section{Methods used}

This study aimed at ascertaining the extent to which the lockdown and other societal aspects of COVID-19 have impacted researchers and influenced their studies on sustainable development. To address the established goal, a crosssectional descriptive study was performed. The descriptive approach is frequently used when little research has been done in an area to understand new concepts or phenomena (Tarzian and Cohen 2011).

To assess the impacts of the crises caused by COVID-19 on sustainable development research, a questionnaire was delivered via a sophisticated on-line survey. The instrument incorporated three parts, in which 29 questions were grouped and composed as follows: seven open-ended questions, four dichotomous questions, seven closed-ended questions and eleven five-point Likert scale questions. These questions gathered relevant information on aspects such as respondents' backgrounds, the impact of the lockdown on their work in terms of distance learning, workload and challenges faced, as well as future projections regarding the COVID-19 crisis influence on research. The full questionnaire is presented in Appendix A. A pre-test was carried out by a group of academics whose fields of expertise lie within the scope of sustainable development research (Hair et al. 2010).

The final version of the survey was implemented through the Google Forms system and distributed by email, collecting responses for 5 weeks (13th April to 19th May). Using the snowball sampling strategy, the instrument was initially shared with the Inter-University Sustainable Development Research Programme (IUSDRP) and also within each co-author's institution.

The analysis procedure involved: (a) the Statistical Package for the Social Sciences-SPPS for quantitative data analysis, in which the following tests were performed: frequency, mean and a correlation of factors, and (b) the qualitative analysis by Nvivo Software was performed, performing tests of frequency and word cloud, applied to the 50 main terms. The qualitative approach adopted here followed the experiences documented by Bardin (2011).

In total, 205 responses were received from all continents and 39 different countries: Australia, Austria, Belgium, Brazil, Canada, China, Colombia, Ethiopia, Finland, Germany, Greece, Guatemala, India, Indonesia, Iran, 
Ireland, Israel, Italy, Kenya, Malaysia, Malta, Mexico, Netherlands, Nigeria, Norway, Pakistan, Poland, Portugal, Romania, Scotland, Serbia, South Africa, Spain, Sweden, Switzerland, Turkey, the United Arab Emirates, the United Kingdom and the United States of America (Fig. 1).

More than $40 \%$ of the sample are from Europe, the continent that reported more than 1,900,000 cases and more than 170,000 deaths 5 months after WHO was informed of cases of pneumonia of unknown cause in China and a novel coronavirus was identified as the root of these disease cases (WHO 2020f; ECDC 2020). Among European respondents, $31 \%$ were from Portugal, where over 32,000 cases were registered, and almost 1,400 deaths in the 5 months of COVID-19 (SNS 2020). Respondents from South and North America countries represent 32 and 15\% of the sample, respectively. Regarding South America,
Brazil represents $98.5 \%$ of the respondents and Mexican participants perform more than half $(55 \%)$ of the North American participants. Since the beginning of the outbreak of the novel coronavirus, Mexico is in the 15th position amongst countries with the most confirmed cases in the world, and Brazil has the second-highest number, after the United States-all three of which are located in the American continent (JHU 2020).

For the scope of the study, Fig. 2 presents the main sample features of the respondents: (a) type of institution; (b) academic position; (c) gender.

The sample also reveals that $94 \%$ of the respondents hail from universities and $6 \%$ represent institutes of technology or other higher education institutions. An academic career in universities has different routes in each country; however, many academic jobs include teaching and conducting
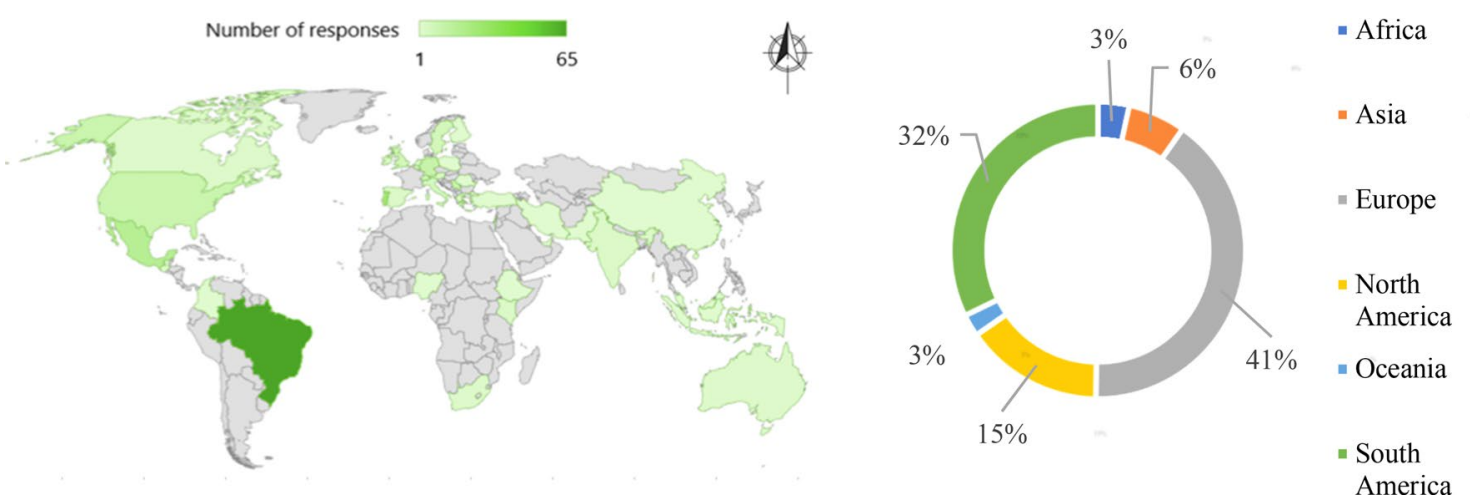

Fig. 1 Sample countries/continents

(a)

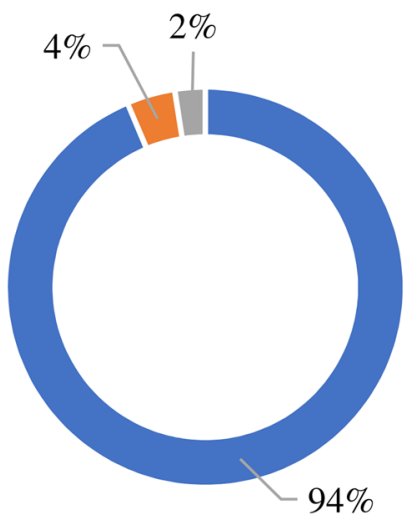

- Universities

- Institute of Technology

- Others HEIs (b)

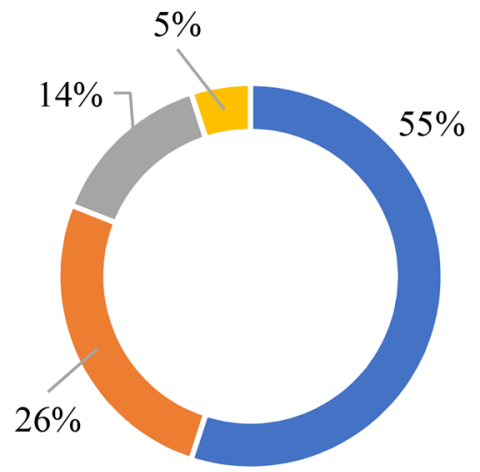

- Professor, teacher, lecturer

- Researcher

- Research fellow, student

- Leadership position (c)

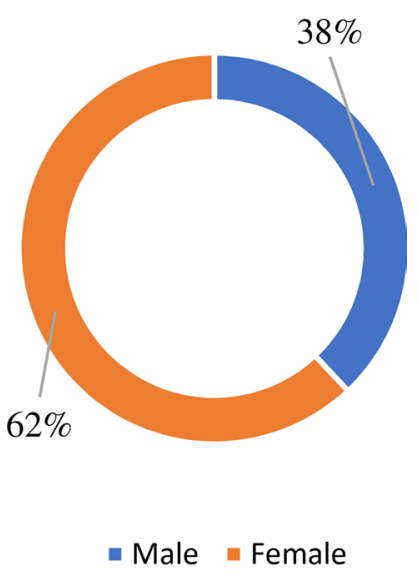

Fig. 2 Characteristics of the respondents: a type of institution, $\mathbf{b}$ academic position, and $\mathbf{c}$ gender 
research in professor or lecturer positions. Over half (55\%) of the participants were academic staff (professors, teachers, lecturers) and $26 \%$ were researchers with knowledge about sustainable development research. Sixty-two percent of the respondents identified themselves as female, highlighting the representativeness of women in the research field. Engineering, manufacturing, and construction (25\%), natural sciences, mathematics, and statistics (21\%), and business, administration, and law (18\%), as well as education (16\%), were the research areas most cited by the sample. The first two are areas that require, in many cases, practical activities in laboratories or outdoor fields.

The main limitation of the study relates to the geographic coverage of the study, with only $6 \%$ of the study from the Asia region. There is a significant amount of sustainability research undertaken in this region, and it is expected that researchers in China (where the initial lockdown occurred) may well have a different experience of how the lockdown has affected their research work.

\section{Results and discussion}

\section{The shutdown and impact on researchers}

The first part of the survey asked respondents about the conditions in which they performed their job during the shutdown. Figure 3 shows how long the research had been affected by the shutdown (a) and the level of the researchers' agreement regarding the adopted measures (b).

Most of the sample (82\%) indicated that they were unable to carry out their research, with $52 \%$ of respondents indicating that this was for a period of between 1 and 2 months. This reflects the current understanding, which argues that to minimise the spread of COVID-19, it is necessary to mitigate the risk of exposure, not only to COVID-19 cases but also to asymptomatic carriers who may harbor the virus and, therefore, pose a significant risk to the health of other people (Kimbrough 2020).

It also reflects the timing of the mass closure of universities and research institutions (UNESCO 2020), when research centers were redesigning their research policies and implementing emergency operation plans (McKinsey and Company 2020; Wang et al. 2020; Omary et al. 2020). This was particularly the case in relation to the potential damage or complete loss of research, and the need to keep plants or animals alive during university and laboratory closures (Kimbrough 2020). Almost a fifth of respondents (18\%) stated that they were able to continue conducting their research normally. Twenty five percent of them do research in engineering, manufacturing and construction (Fig. 4), and $17 \%$ percent are doing research in more than one specific field. More than $30 \%$ are researching in fields that need less access to specialist scientific labs and resources, such as business, administration, law, social sciences, journalism, information and education.

Although the majority of the sample stated that they were unable to conduct their research normally at university, almost $88 \%$ either agreed or strongly agreed with the actions taken by their institution during this period, almost $6 \%$ either disagreed or strongly disagreed, and $6 \%$ neither agrees nor disagrees. Such agreement might reflect the scale and significance of the issue which are encapsulated within the WHO guidelines to maintain social distance, or the fear that people have of being contaminated or contaminating their relatives who belong to some risk group (Rajagopaian et al. 2020). The implication for research institutes suggests that acting in line with WHO or other agency advice is helpful to retain the support of their researchers.

Driven by the need for social distancing and individual executive orders from the state, many institutions have been severely reducing onsite research and maintaining there only the activities considered essential. Research activities considered critical are allowed, with the possibility
Fig. 3 Shutdown time (a) and level of agreement (b) (a)

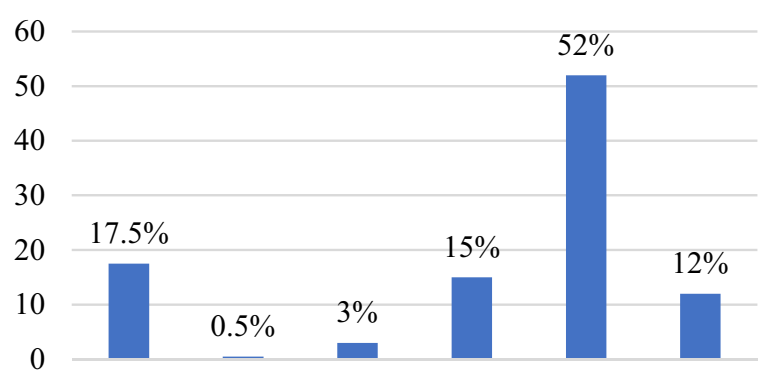

(b)

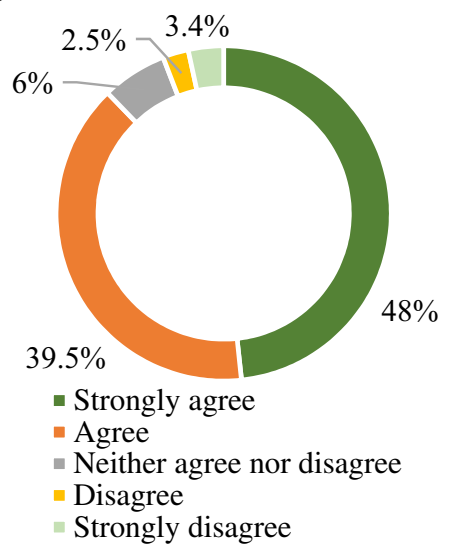


Fig. 4 Research fields able to perform research normally

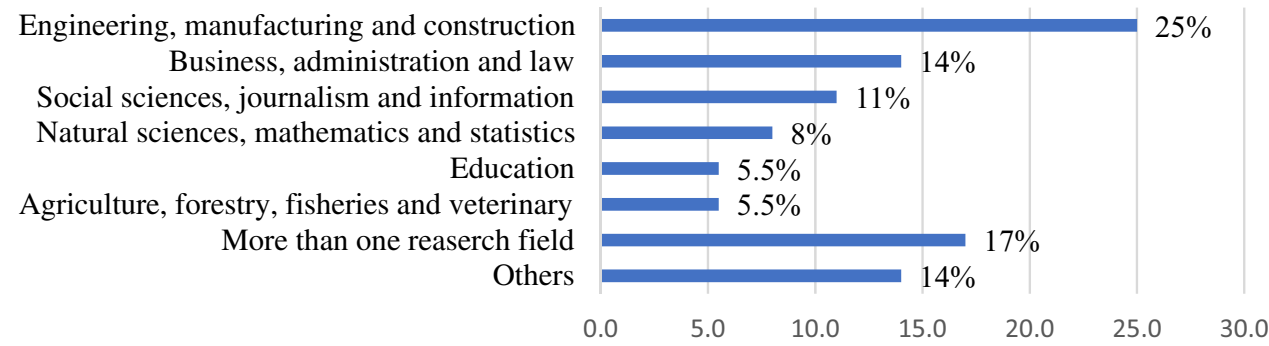

of the presence of a single 'critical laboratory member' on-site at a time, with a possible rotation system (Omary et al. 2020). During the crisis caused by COVID-19, most researchers $(86.5 \%)$ have worked only from the home office. The researchers considered the available infrastructure to perform the work on sustainability research from home 'acceptable' (38\%) and 'good' (32\%), and $41 \%$ of the sample considered the support for research given by their institute as 'good' or 'very good'. Figure 5 shows the research workplaces during the crisis (a) and how the researchers evaluate their infrastructure and institute support during the COVID-19 crisis (b). This supports the earlier implication for research institutes to provide appropriate and relevant support, perhaps differentially across research fields.

The access and consultation of journal articles (30\%) and the use of on-line media reports $(18 \%)$ were reported as the main means of information necessary for performing the research during the shutdown. Sustainability-oriented research requires transdisciplinary models to solve socioenvironmental problems, and communication among the researchers is essential (Klenk and Meehan 2017). Therefore, apart from e-mail, the sample used videoconferencing tools to communicate with research groups or attend meetings, such as Zoom (35\%) and Skype (29\%). Other responses mainly included Microsoft Teams and Google tools (Meeting, Classroom, and HangOut) (11\%). Figure 6 represents the main information means and communication tools used during shutdown. The use of technologies in sustainability research is an important strategy for the shutdown period, and it can impact sustainability research beyond the pandemic (Show et al. 2020; Zhou et al. 2020a, b). The implication of this is to provide professional development and support in relation to the use of technologies to support ongoing research activity.

\section{The shutdown and impacts on research}

This part of the survey aimed to understand the extent to which the lockdown triggered by COVID-19 has influenced research. Around $60 \%$ of the respondents suggested that the lockdown has had negative or very negative influences on their research (from 'a little bit' to 'a great extent'), 30\% reported neutral effects, and $11 \%$ reported a 'positive' or 'very positive' influence on their research. The neutral effects might be explained by the $18 \%$ who are still able to perform their research under COVID lockdown (Fig. 3a). Nevertheless, $61.5 \%$ of the sample reported that the main direction of the research has not been adapted or changed as a consequence of this pandemic. Table 1 shows the extent to which the shutdown has influenced research and the nature of the influence.

Impacts on research caused by closures have been reported in different scientific areas (Nature Medicine 2020), and the extant literature suggests that the most negative impacts are predominantly related to delays and adjustments in the projects' schedules and programs (Pope 2020).
Fig. 5 Workplace (a), infrastructure and institutional support (b) (a)

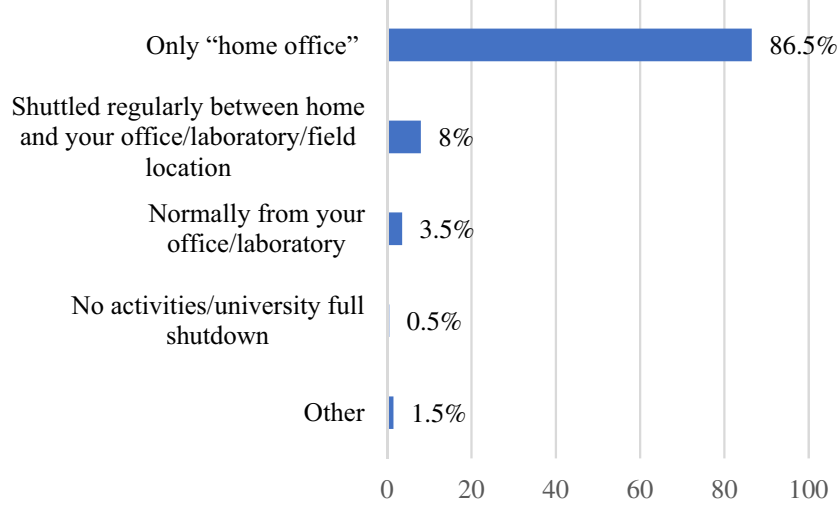

(b)

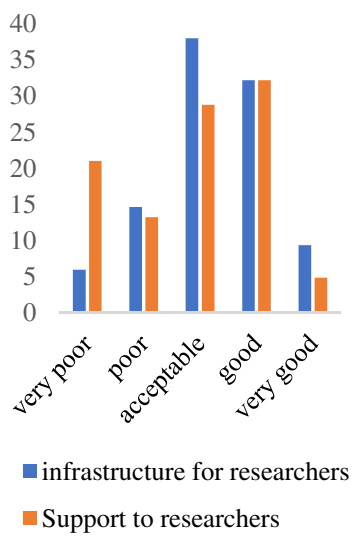


Fig. 6 Information means and communication tools (a)

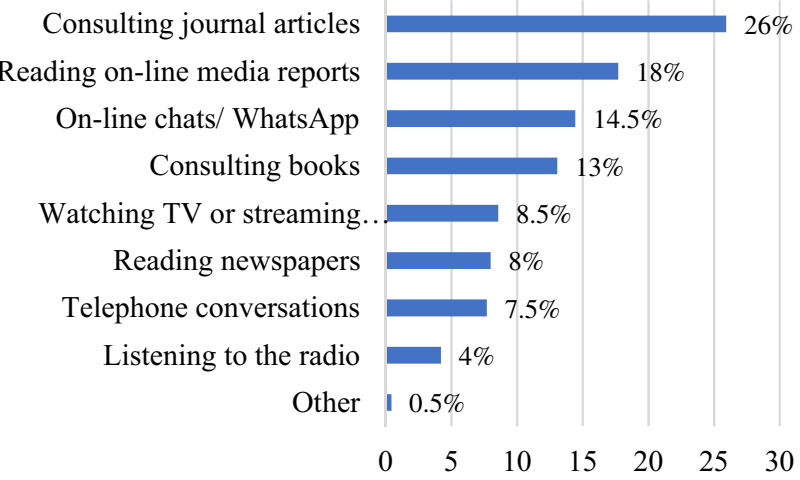

(b)

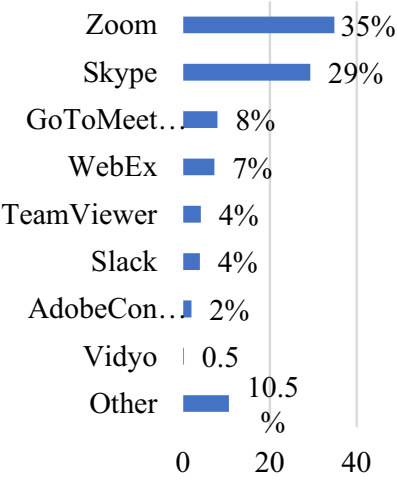

Table 1 The extent to which the shutdown has influenced research

\begin{tabular}{|c|c|c|c|c|c|c|c|c|c|c|c|}
\hline & & \multicolumn{10}{|c|}{ Has this influence been... } \\
\hline & & \multicolumn{2}{|c|}{$\begin{array}{l}\text { Very } \\
\text { negative }\end{array}$} & \multicolumn{2}{|c|}{ Negative } & \multicolumn{2}{|c|}{ Neutral } & \multicolumn{2}{|c|}{ Positive } & \multicolumn{2}{|c|}{$\begin{array}{l}\text { Very } \\
\text { posi- } \\
\text { tive }\end{array}$} \\
\hline & & $N$ & $\%$ & $N$ & $\%$ & $N$ & $\%$ & $N$ & $\%$ & $N$ & $\%$ \\
\hline \multirow[t]{6}{*}{ To which extent has the shutdown influenced your research? } & Not at all & 0 & 0.0 & 0 & 0.0 & 5 & 100.0 & 0 & 0.0 & 0 & 0.0 \\
\hline & A little bit & 0 & 0.0 & 21 & 51.2 & 15 & 36.6 & 4 & 9.8 & 1 & 2.4 \\
\hline & To some extent & 0 & 0.0 & 36 & 51.4 & 25 & 35.7 & 9 & 12.9 & 0 & 0.0 \\
\hline & To a moderate extent & 1 & 1.8 & 36 & 65.5 & 12 & 21.8 & 6 & 10.9 & 0 & 0.0 \\
\hline & To a great extent & 9 & 26.5 & 19 & 55.9 & 3 & 8.8 & 1 & 2.9 & 2 & 5.9 \\
\hline & Total & 10 & 4.9 & 112 & 54.6 & 60 & 29.3 & 20 & 9.8 & 3 & 1.5 \\
\hline
\end{tabular}

The sample suggested a more nuanced analysis of these impacts, such as substantial adjustments in the project's schedule $(28 \%)$, delays $(26.5 \%)$, project meeting cancellations $(22.5 \%)$, and disrupted communication (19\%). Impacts on research workload were reported by $83.5 \%$ of the participants, with some experiencing a decrease in workload $(42.5 \%)$ and others a moderate or great increase in workload $(41 \%)$. The respondents also reported difficulties in adapting to the home office regime and in following their research.

The main challenges related to COVID-19 shutdown that were experienced by sustainability researchers were the lack of personal interaction and dialogue with colleagues or research stakeholders $(37 \%)$, the lack of materials or resources (20\%), and the lack of interest or motivation (18\%). The shutdown has increased the use of communication technologies; academic and scientific staff members have become more familiar with these tech-tools, and these digital technologies have a significant influence on the alignment with the objectives of sustainable development (Beier et al. 2020). However, these results perhaps highlight the need for face-to-face interaction in sustainability research, which is often transdisciplinary and collaborative (Heaphy and Dutton 2008; Nie and Hillygus, 2002). It might be the case that some researchers fear that an additional emphasis on technology-mediated perceptions of reality may amplify existing disconnections (ibid). Figure 7 illustrates the challenges researchers have overcome during the coronavirus shutdown.

The lack of materials and resources might be related to the logistical changes and difficulties in delivering raw material and inputs for research or office materials for basic administrative tasks associated with research. Around a fifth of participants reported a lack of support in relation to the administration (11\%) and lack of expertise in the use of technologies (also 11\%), which echoes perceptions of those researchers who rate the support given by research establishments as 'poor' or 'very poor' (30\% of the sample-Fig. 5b). These challenges represent high uncertainty for sustainability research (Ivanov 2020).

Despite the negative impacts and challenges, some sustainability researchers used the open answers to point out other positive aspects within their regime of work, such as bond improvements with relatives, being able to spend extra time with family members, and learning about their 


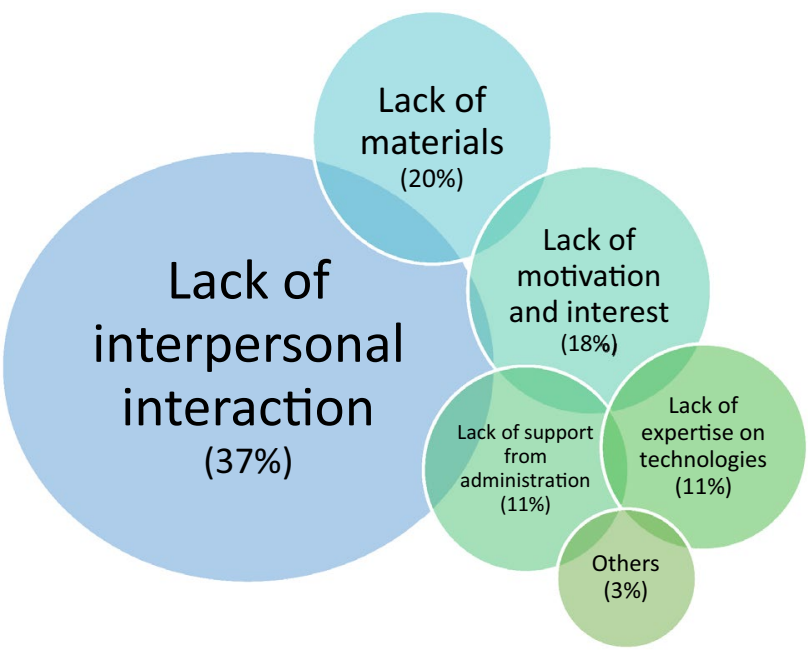

Fig. 7 Challenges during the coronavirus shutdown

personal and professional life. Such sensations of social connection and belonging are fundamental to people's physical, mental, and professional well-being (Omary et al. 2020). Again using the open answers, researchers reported that the physical and social isolation, associated with maintaining the research activities from the home office, has opened to them to a new universe (something that rarely used to occur before the novel coronavirus); this new experience has stimulated empathy and solidarity on a daily basis, as well as the ability to produce more, as they have more time to devote exclusively to research. Figure 8 shows the 50 most representative terms of the responses to the open-ended question about the main impacts of the pandemic crisis on research focused on sustainability. The analysis shows that the impact of COVID-19 influenced the following aspects: (a) academic activities; (b) work-family relations; (c) health effects; (d) increased online meetings; (e) psychological aspects; (f) opportunity for new projects; (g) opportunities for new research; (h) sharing social and sustainable aspects with the community; (i) adapting to the new teaching system; (j) thinking about new research topics; (1) creating new working methods at the university; and ( $\mathrm{j}$ ) actions for the community and partnerships. The pandemic has created a new scenario for science professionals and institutions, bringing with it a scenario for rapid adaptation to change, problems and also opportunities as new drivers for research agendas and projects for sustainability. These aspects also reflect the challenges of the lockdown and the home office.

Figure 9 shows that several participants (42.5\%) strongly agree that there is an adaptation or change in the way research is done, adding more on-line meetings and using more on-line resources; they expect this to continue in some way after the crisis, since it reduces the need for people to travel and move around, providing an economy of time for these people and collaborating in the reduction of carbon emissions. Almost 78\% agree or strongly agree that the COVID-19 crisis has generated environmental and social impacts. Cicala et al. (2020) cite that during social distancing in Los Angeles, there was a reduction in carbon emissions of 1.1 million metric tons. Authors also affirm that behavioural changes in other major cities also led to substantial reductions in $\mathrm{CO} 2$ emissions.

Also in Fig. 7, it is possible to observe that over half of the sample (53\%) 'agree' that the impact of the COVID19 crisis has influenced the way researchers understand or interpret change in wider systems, and almost $40 \%$ of the sample reported changes in project planning and new proposals focused on issues such as a health crisis, climate change, resilience, and environment, among others. The COVID-19 topic has been added as a topic in current research activities by $39 \%$ of the researchers, and $33 \%$ 'agree' or 'strongly agree' that a review of research methods to highlight the impact of this crisis on life was assumed. These results reinforce the role of sustainabilityoriented research in addressing transdisciplinary issues that may trigger social and environmental impacts (Klenk and Meehan 2017).

The discussion above highlights how the research environment of sustainability researchers could be adapted to
Fig. 8 Open answers' word cloud academic activities basis communities concentrate Covid crisis development effect family global health home human impact increases issue lack life managed meetings opportunity pandemic people physical produce productivity project provided

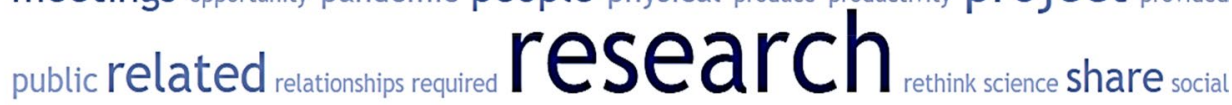
space support sustainable systems teaching terms thesis think topic traveling university WOrk 
COVID-19 may change the way universities do research

Despite all challenges, the COVID-19 crisis provided some positive impacts

I have added COVID-19 as a topic on current research activities

I have revised my research methods to highlight the impact of the COVID-19 crisis on life as we knew it

The impact of the COVID-19 crisis has influenced how I interpret change in systems

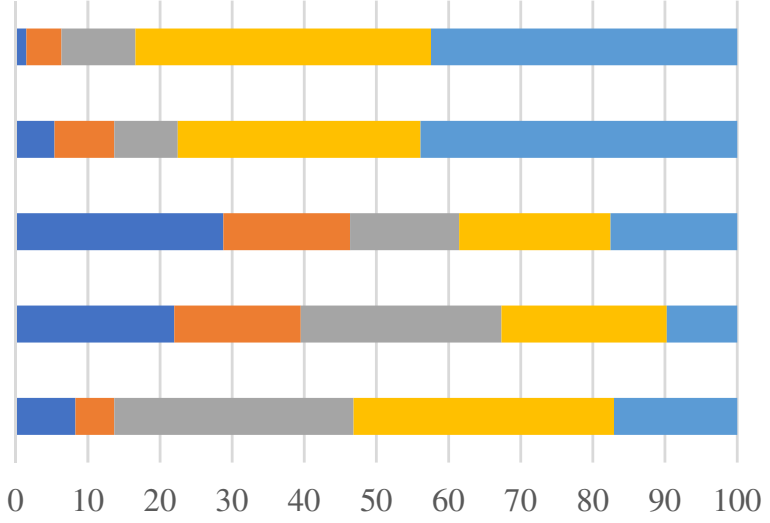

$\square$ Strongly agree $\square$ Agree $\square$ Neither agree nor disagree $\square$ Disagree $\square$ Strongly disagree

Fig. 9 Level of agreement (\%) for some COVID-19 impacts on sustainable development research

enable researchers to adapt when they are required to. This would include both the practical and administrative flexibilities that are required to do their work, but also the capabilities to be able to flex within their own research practise. This does not only include the sites in which their work is conducted, but also the ways in which they conceptualise the methodological aspects of their research (and most probably the theoretical dimensions which are linked to their methodological commitments). However, it is likely that research establishments need to be sensitive to the differential impacts across disciplinary fields, and so will need to reflect this in their own strategies and policies.

\section{The shutdown and the future of sustainability research}

The last part of the survey aimed to offer an understanding of future perceptions of the respondents on how sustainability research will be performed after the COVID-19 pandemic. The majority of the sample (82\%) 'agree' that the COVID19 crisis will influence research in the long-term. Figure 10 presents the main ways the respondents believe this influence will occur.
The most common, longer term influence of COVID-19 reported by researchers (39\%) was that more technological resources would be deployed for coping with working from home. This is reflected in other studies which argue that the next generation of researchers will retain the memory of living and working through the crisis with them throughout their careers and will be shaped by the environment created by the situation (Omary et al. 2020). For example, the more extensive use of virtual lab meetings, research seminars, conferences, events, and meetings with students and fellow researchers will cause an increase in the current frequency and speed at which current activity is being organised (Omary et al. 2020). Therefore, it is necessary to adapt and shift to more IT-based communication technologies and consider the possibility of extreme events when preparing new schedules for research development (Djalante et al. 2020).

The degree to which COVID-19 will have lasting impacts on sustainability science research is unclear (Cohen 2020). New research opportunities are emerging, such as the European Commission's recent announcement of up to $€ 140$ million to research the COVID-19 crisis (EU 2020). In this sense, many of the researchers responding to the study $(60 \%)$ also reported an increase in creativity or new ideas
Fig. 10 COVID-19 impacts on sustainable development research in the future
Use more technological resources for a "home office" working mode

Better consider the possibility of "extreme events" when preparing research schedules

Greater reliance on IT-based communication technologies for research

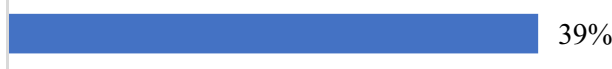

$32 \%$

Other

$1 \%$ 
for their sustainable development research, despite the complex nature of this kind of research, such as understanding disaster and health-related emergency risks and responding to local and global demands (Djalante et al. 2020; Leahey and Barringer 2020; Caniglia et al. 2017). Research institutions, by implication, will need to consider how to move some of their research support functions, for example, grant writing and costing support teams, to operation in online environments.

\section{Conclusions}

This study aimed to foster a better understanding of the impacts of the COVID-19 lockdown on sustainable development research; our survey coincided with the period immediately after the peak in several European countries, the confirmation of COVID-19 in all North American territories, and the rapidly rising count in South America. The information gathered highlight important aspects of the impact of COVID-19 in terms of daily-based research routines. It also illustrates the adaptation measures needed to allow a continuation of research-along with teaching and other university activities-as well as future planning and the capacity to resume sustainable development research.

This study has some limitations. First, it focused on sustainability research only and not on other activities. The reason for this is that the project teams have also undertaken other studies that look, for instance, at the impacts of the COVID-19 pandemic on teaching. Second, the sample is limited to 205 responses, and this can by no means be regarded as representative of the world academic community.

But the fact that these responses have been provided by academics from 39 countries in all continents who are active in sustainability research means that a rough profile of the opinions from researchers can be built. An advantage of the study is that it is one of the very few which are fully devoted to research on sustainable development.

In terms of gender issues, almost two-thirds of the respondents were female, and $14 \%$ of them were students or researcher fellows. Such results are consistent with the reflections of the impact of COVID-19: (1) on academic mothers (Staniscuaski et al. 2020; Gibson et al. 2020) and how this pandemic is exacerbating the gender inequalities in science; and (2) on students and research fellows and how the interruption of scientific activities will be reflected in their research work, which is typically based on insecure contracts (Inouye et al. 2020; Gibson et al. 2020).

The study did not explore the impact of COVID-19 closures in terms of the individuals' contexts, but many scientific journals contain testimonies from researchers who are facing challenging responsibilities regarding family (Staniscuaski et al. 2020). Flexible-work from home has been adopted in most institutions, but again the expectations and adjustments seen in the modalities of remote working have not been reported evenly in the sustainable development research field. About one-eighth of our sample was from the natural and agricultural sciences, onequarter from engineering and technology, and one-third from fields that need less access to specialist scientific labs and resources.

Despite the constraints on continuing current research activities, which were reported by the majority of our sample, about $90 \%$ stated that they agree with the lockdown measures and $40 \%$ believe that their research institutions are supporting them.

Over half of our sample admitted that the impact of the COVID-19 crisis influenced new angles of interpreting changes in wider complex systems, and almost $40 \%$ reported the intention of considering the health crisis, climate change, resilience, and environment, among others, in new research proposals.

After a period of meetings cancelled all over the world, scientists have discovered the upside of innovative and hightech solutions, such as video conferencing, that provide the opportunity for virtual meetings while also making an important contribution to the move forward towards a lowcarbon economy. Despite this advantage, one of the main challenges experienced by sustainability researchers was a lack of personal interaction, such as in participatory research involving multi-stakeholder groups.

Scientific journals have also been facilitating free access to COVID-19 papers, bringing forth new opportunities for integrating science and rethinking sustainable development research without borders.

By the time this paper has been prepared, about one in five individuals worldwide could be at risk of being affected by the COVID-19 pandemic (Clark et al. 2020). The challenges brought by COVID-19 also opens venues for further research on data collection methods and procedures that require personal interactions and face-to-face interviews, as these methodological transitions require changes in traditional collection instruments and data analysis, as debated by Burton et al. (2020) or Will et al. (2020).

Some of the measures that may be implemented in the future, towards a greater support of research on sustainable development, are:

(a) Better planning of sustainable development research in a way that it becomes more resilient to such pandemics;

(b) A more systematic use of existing technologies in a way that they may support research, for instance, a wider use of international, multilingual scientific studies and a greater dissemination of their findings and knowledge; 
(c) Greater reflection on the adequacy of some research methods, so that studies may be undertaken even in the case of lockdowns;

(d) Consideration of the carbon neutrality of research, coupled with social innovation. This includes, for instance, how institutions may adapt their research labs and campus facilities for a greater provision of technical training and online support, which may help to make research projects more efficient.

Finally, the COVID-19 pandemic has shown that, with due care and planning, research activities on matters related to sustainable development may become more resilient, without endangering the quality of the works performed.

Author contributions All authors contributed to the study conception and design of the paper. All authors read and approved the final manuscript. WLF: conceptualization, supervision, writing —original draft preparation, writing — reviewing and editing. AMA: writing - original draft, writing - reviewing and editing. TW: methodology, writingreviewing and editing. CRPV: methodology ALS: methodology. AP: writing — original draft. KS: writing — original draft. VL: writingoriginal draft FD: writing — original draft. LA-C: writing—original draft. CM: methodology. LVÁ: formal analysis, writing —original draft. LID: writing — original draft. PC: formal analysis, writing - original draft. UMA: writing — original draft. BF: writing —original draft. PF: writing — original draft. FF: writing — original draft.

\section{Compliance with ethical standards}

Conflict of interest The authors declare that they have no conflict of interest.

\section{References}

Amanat F, Krammer F (2020) SARS-CoV-2 vaccines: status report. Immunity 52(4):583-589. https://doi.org/10.1016/j.immun i. 2020.03 .007

Angeloni S (2020) Education first: what really matters in working for sustainability. Futures 120:102552. https://doi.org/10.1016/j.futur es.2020.102552

Bardin L (2011) Análise de conteúdo. SPEdições 70:2011

Beier G, Ullrich A, Niehoff S, Reißig M, Habich M (2020) Industry 4.0: How it is defined from a sociotechnical perspective and how much sustainability it includes - a literature review. J Clean Prod 259:120856. https://doi.org/10.1016/j.jclepro.2020.120856

Berchin II, Sima M, Andrade de Lima M, Biesel S, Piazza dos Santos L, Ferreira RV, de Andrade Guerra JBSO, Ceci F (2018) The importance of International Conferences on Sustainable Development as Higher Education Institutions' strategies to promote sustainability: a case study in Brazil. J Clean Prod 171(10):756-772. https://doi.org/10.1016/j.jclepro.2017.10.042

Bergvall-Kåreborn B, Ståhlbröst S (2009) Living lab: an open and citizen-centric approach for innovation. Int J Innov Region Dev 1(4):356-370. https://doi.org/10.1504/IJIRD.2009.022727

Burton J, Lynn P, Benzeval M (2020) How Understanding Society: the UK Household Longitudinal Study adapted to the
COVID-19 pandemic. Surv Res Methods 14(2):235-239. https ://doi.org/10.18148/srm/2020.v14i2.7746

Caniglia G, Lang D et al (2017) Transnational collaboration for sustainability in higher education: lessons from a systematic review. J Clean Prod 168:764-779. https://doi.org/10.1016/j. jclepro.2017.07.256

Chan JF-W, Kai-Wang To K, Tse H, Jin D-Y, Yuen K-Y (2013) Interspecies transmission and emergence of novel viruses: lessons from bats and birds. Trends Microbiol 21(10):544-555. https:// doi.org/10.1016/j.tim.2013.05.005. https://www.sciencedirect. com/science/article/pii/S0966842X13000899

Cicala S, Holland SP, Mansur ET, Muller NZ, Yates AJ (2020) Expected health effects of reduced air pollution from COVID19 social distancing. NBER Working Paper Series, WP 27135. https://doi.org/10.3386/w27135

Clark A, Jit M, Warren-Gash C, Bruce Guthrie B, Wang HHX, Mercer SW, Sanderson C, McKee M, Troeger C, Ong KL, Checchi F, Perel P, Joseph S, Gibbs HP, Banerjee A, Eggo RM, with the Centre for the Mathematical Modelling of Infectious Diseases COVID-19 working group (2020) Global, regional, and national estimates of the population at increased risk of severe COVID19 due to underlying health conditions in 2020: a modelling study. Lancet. https://doi.org/10.1016/S2214-109X(20)30264-3

Cohen MJ (2020) Does the COVID-19 outbreak mark the onset of a sustainable consumption transition? Sustain Sci Pract Policy 16(1):1-3

Djalante R, Shaw R, DeWit A (2020) Building resilience against biological hazards and pandemics: COVID-19 and its implications for the Sendai Framework. Progr Disaster Sci 6:100080

ECDC Europe (2020) COVID-19 situation update worldwide, as of 30 May 2020. Available at: https://www.ecdc.europa.eu/en/ geographical-distribution-2019-ncov-cases. Accessed 30 May 2020

European Commission-EU (2020) Coronavirus research and innovation. Available at https://ec.europa.eu/info/research-and-innov ation/research-area/health-research-and-innovation/coronaviru s-research-and-innovation_en. Accessed 18 Apr 2020

European Environment Agency's (EEA). Air pollution goes down as Europe takes hard measures to combat coronavirus. Available at https://www.eea.europa.eu/downloads/4af3d2f4196345848b1c fe9571df271c/1586244790/air-pollution-goes-down-as.pdf. Accessed 18 Apr 2020

Fong S, Li G, Dey N, González R, Herrera E (2020) Composite Monte Carlo decision making under high uncertainty of novel coronavirus epidemic using hybridized deep learning and fuzzy rule induction. Appl Soft Comput. https://doi.org/10.1016/j. asoc.2020.106282

Gibson EM, Bennett FC, Gillespie SM et al (2020) How support of early career researchers can Reset Science in the Post-COVID19 World. Cell 8674(20):30678-30684. https://doi.org/10.1016/j. cell.2020.05.045

Gummer T, Schmiedeberg C, Bujard M, Christmann P, Hank K, Kunz T, Lück D, Neyer FJ (2020) The impact of Covid-19 on fieldwork efforts and planning in pairfam and FReDA-GGS. Surv Res Methods 14(2):223-227. https://doi.org/10.18148/srm/2020.v14i2 .7740

Hair JF Jr, Black WC, Babin BJ, Anderson RE (2010) Mutilvariate data analysis, 7th edn. Prentice, Upper Saddle River

Heaphy ED, Dutton JE (2008) Positive social interactions and the human body at work: linking organizations and physiology. AcadManag Rev 33(10):137-162

Inouye DW, Underwood N, Inouye BD, Irwin RE (2020) Support earlycareer field researchers. Science 368(6492):724-725. https://doi. org/10.1126/science.abc1261

Ivanov D (2020) Predicting the impacts of epidemic outbreaks on global supply chains: a simulation-based analysis on the 
coronavirus outbreak (COVID-19/SARS-CoV-2) case. Transp Res Part E LogistTransp Rev 136:101922. https://doi.org/10.1016/j. tre.2020.101922

JHU (2020) COVID-19 Dashboard by the Center for Systems Science and Engineering (CSSE) at Johns Hopkins University (JHU). Available at: https://coronavirus.jhu.edu/map.html. Accessed 30 May 2020

Johnson CK, Hitchens PL, Pandit PS, Rushmore J, Evans TS, Young CCW, Doyle MM (2020) Global shifts in mammalian population trends reveal key predictors of virus spillover risk. Proc R Soc B 287:20192736. https://doi.org/10.1098/rspb.2019.2736

Kimbrough L (2020) Field research interrupted: How the COVID-19 crisis is stalling science. Mongabay News. Available at: https:// news.mongabay.com/2020/04/field-research-interrupted-how-thecovid-19-crisis-is-stalling-science/. Accessed 18 Apr 2020

Klenk N, Meehan K (2017) Transdisciplinary sustainability research beyond engagement models: toward adventures in relevance. Environ Sci Policy 78:27-35. https://doi.org/10.1016/j.envsc i.2017.09.006

La V-P, Pham T-H, Ho M-T, Nguyen M-H, Nguyen K-L, Vuong T-T, Nguyen H-KT, Tran T, Khuc Q, Ho M-T, Vuong Q-H (2020) Policy response, social media and science journalism for the sustainability of the public health system amid the COVID-19 outbreak: the Vietnam lessons. Sustainability 12:2931

Lam TT, Shum MH, Zhu H, Tong Y-G, Ni X-B, Liao Y-S, Wei W, Cheung WY-M, Li L-F, Leung GM, Holmes EC, Hu Y-L, Guan Y (2020) Identifying SARS-CoV-2 related coronaviruses in Malayan pangolins. Nature. https://doi.org/10.1038/s41586-020-2169-0

Leahey E, Barringer S (2020) Universities' commitment to interdisciplinary research: to what end? Res Policy 49(2):103910. https:// doi.org/10.1016/j.respol.2019.103910

Leone F (2020) COVID-19 pandemic disrupts UN meeting plans around the world 19th March 2020. Available at https://sdg.iisd. org/news/covid-19-pandemic-disrupts-un-meeting-plans-aroun d-the-world/. Accessed 18 Apr 2020

McKinsey \& Company (2020) How can campus Coronavirus and the campus: How can US higher education organize to respond? Available at https://www.mckinsey.com/ /media/McKinsey/Indus tries/Public\%2520Sector/Our\%2520Insights/Coronavirus\%2520a nd $\% 2520$ the $\% 2520$ c ampus $\% 2520$ How $\% 2520$ c an $\% 2520 \mathrm{U}$ S\%2520higher\%2520education\%2520organize\%2520to\%2520r espond/Coronavirus-and-the-campus-How-can-US-higher-educa tion-organize-to-respond.ashx. Accessed 15 Apr 2020

Nature Medicine (2020) Safeguard research in the time of COVID19. Nat Med 26:443. https://doi.org/10.1038/s41591-020-0852-1

Nie NH, Hillygus DS (2002) The impact of Internet use on sociability: time-diary findings. IT Soc 1(1):1-20

Omary MB, Eswaraka J, Kimball SD, Moghe PV, Panettieri RA, Scotto KW (2020) The COVID-19 pandemic and research shutdown: staying safe and productive. J ClinInvestig 130(6):2745-2748. https://doi.org/10.1172/JCI138646

Pope K (2020) How scientists are keeping irreplaceable research going during the COVID-19 pandemic. Smithsonian Mag. Available at: https://www.smithsonianmag.com/science-nature/science-cance led-coronavirus-180974449/. Accessed 18 Apr 2020

Rajagopaian S, Huang S, Brook RD (2020) Flattening the curve in COVID-19 using personalised protective equipment: lessons from air pollution. Hearth Month 0:1-3. https://doi.org/10.1136/heart jnl-2020-317104

Rau H, Goggins G, Fahy F (2018) From invisibility to impact: recognising the scientific and societal relevance of interdisciplinary sustainability research. Res Policy 47(1):266-276. https://doi. org/10.1016/j.respol.2017.11.005

Salata C, Calistri A, Parolin C, Palù G (2019) Coronaviruses: a paradigm of new emerging zoonotic diseases. Pathog Dis. https://doi. org/10.1093/femspd/ftaa006
Sastry N, McGonagle K, Fomby P (2020) Effects of the COVID-19 crisis on survey fieldwork: experience and lessons from two major supplements to the US Panel Study of income dynamics. Surv Res Methods 14(2):241-245. https://doi.org/10.18148/srm/2020. v14i2.7752

Scherpenzeel A, Axt K, Bergmann M, Douhou S, Oepen A, Sand G, Schuller K, Stuck S, Wagner M, Börsch-Supan A (2020) Collecting survey data among the 50+ population during the COVID19 outbreak: the Survey of Health, Ageing and Retirement in Europe (SHARE). Surv Res Methods 14(2):217-221. https://doi. org/10.18148/srm/2020.v14i2.7738

Schneidewind U (2014) Von der nachhaltigen zur transformativenHochschule. Perspektiveneiner "True University Sustainability". UwfUmweltWirtschaftsForum 22(4):221-225. https://doi. org/10.1007/s00550-014-0314-7

Shang J, Ye G, Shi K, Wan Y, Luo C, Aihara H, Geng Q, Uerbach A, Li F (2020a) Structural basis of receptor recognition by SARSCoV-2. Nature 581:221-224. https://doi.org/10.1038/s4158 6-020-2179-y

Shang W, Yang Y, Rao Y et al (2020b) The outbreak of SARS-CoV-2 pneumonia calls for viral vaccines. npj Vaccines. https://doi. org/10.1038/s41541-020-0170-0

Show R, Kim Y, Hua J (2020) Governance, technology and citizen behavior in pandemic: lessons from COVID-19 in East Asia. Prog Disaster Sci 6:100090. https://doi.org/10.1016/j.pdisa s.2020.100090

SNS (2020) Ponto de Situação Atual em Portugal. Available at: https ://covid19.min-saude.pt. Accessed 30 May 2020

Spoelstra SF (2013) Sustainability research: Organizational challenge for intermediary research institutes. NJASWageningen J Life Sci 66:75-81. https://doi.org/10.1016/j.njas.2013.06.002

Staniscuaski F, Reichert F, Werneck FP et al (2020) Impact of COVID19 on academic mothers. Science 368(6492):724. https://doi. org/10.1126/science.abc2740

Tarzian AJ, Cohen MZ (2011) Descriptive research. In: Fitzpatrick JJ, Kazer M (eds) Encyclopedia of nursing research, 3rd edn. Springer Publising Company, Berlin, p 732

UNESCO (2020) COVID-19 educational disruption and response. Available at:https://en.unesco.org/covid19/educationresponse. Accessed 31 May 2020

United Nations-UN (2020) UN ocean conference. Available at https:// www.un.org/en/conferences/ocean2020. Accessed 18 Apr 2020

United Nations-UN (2020). SDG Planning Calendar. Available at https ://www.un.org/sustainabledevelopment/sdg-planning-calendar/. Accessed 18 Apr 2020

United Nations Climate Change-UNFCCC (2020) Information on the Coronavirus disease (COIV-19) - implication for meetings. https ://unfccc.int/news/information-on-the-coronavirus-disease-covid -19-implications-for-meetings. Accessed 28 June 2020

Uwaegbulam C (2020) Coronavirus hits a critical year for nature, climate 23rd March 2020. Available at https://guardian.ng/property/ coronavirus-hits-a-critical-year-for-nature-climate/. Accessed 18 Apr 2020

van Kerkhoff L, Lebel L (2006) Linking knowledge and action for sustainable development. Annu Rev Environ Resour 31(1):445-477

Waas T, Verbruggen A, Wright T (2010) University research for sustainable development: definition and characteristics explored. J Clean Prod 18(7):629-636. https://doi.org/10.1016/j.jclep ro.2009.09.017

Wang C, Cheng Z, Yue X-G, McAleer M (2020) Risk Management of COVID-19 by Universities in China. J Risk FinancManag 13(2):36

WHO (2020a) Report of the WHO-China Joint Mission on coronavirus disease 2019 (COVID-19). Available at: https://www.who. int/publications-detail/report-of-the-who-china-joint-missionon-coronavirus-disease-2019-(covid-19). Accessed 8 Apr 2020 
WHO (2020b) General's opening remarks at the media briefing on COVID-19-11 March 2020. Available at: https://www.who.int/ $\mathrm{dg} /$ speeches/detail/who-director-general-s-opening-remarks-atthe-media-briefing-on-covid-19---11-march-2020. Accessed 16 Mar 2020

WHO (2020c) Novel coronavirus (2019-nCoV) situation report-1. 21 January 2020. Available at: https://www.who.int/docs/defau lt-source/coronaviruse/situation-reports/20200121-sitrep-1-2019ncov.pdf?sfvrsn=20a99c10_4. Accessed 8 Apr 2020

WHO (2020d) Novel coronavirus (2019-nCoV) situation report-19. Available at: https://www.who.int/docs/default-source/coronaviru se/situation-reports/20200208-sitrep-19-ncov.pdf?sfvrsn=6e091 ce6_4. Accessed 8 Apr 2020

WHO (2020e) Coronavirus disease 2019 (COVID-19) situation report-48. Available at: https://www.who.int/docs/default-sourc e/coronaviruse/situation-reports/20200308-sitrep-48-covid-19. pdf?sfvrsn=16f7ccef_4. Accessed 8 Apr 2020

WHO (2020f) Coronavirus disease 2019 (COVID-19) situation report-79. Available at: https://www.who.int/docs/default-sourc e/coronaviruse/situation-reports/20200408-sitrep-79-covid-19. pdf?sfvrsn=4796b143_4. Accessed 8 Apr 2020

Wiek A, Talwar S, O'Shea M, Robinson J (2014) Toward a methodological scheme for capturing societal effects of participatory sustainability research. Res Eval 23(2):117-132. https://doi. org/10.1093/reseval/rvt031

Will G, Becker R, Weigand D (2020) COVID-19 lockdown during field work. Surv Res Methods 14(2):247-252. https://doi.org/10.18148 /srm/2020.v14i2.7753

Williams S, Robinson J (2020) Measuring sustainability: an evaluation framework for sustainability transition experiments.
Environ Sci Policy 103:58-66. https://doi.org/10.1016/j.envsc i. 2019.10 .012

WWF (2020) Pandemie, l'effetto boomerang delladistruzionedegliecosistemi (pandemics, the boomerang effects of the destruction of ecosystems). Available at https://d24qi7hsckwe9l.cloudfront .net/downloads/pandemie_e_distruzione_degli_ecosistemi.pdf. Accessed 18 Apr 2020

$\mathrm{Xu} \mathrm{Y} \mathrm{(2020)} \mathrm{Unveiling} \mathrm{the} \mathrm{origin} \mathrm{and} \mathrm{transmission} \mathrm{of} \mathrm{2019-nCoV.}$ Trends Microbiol 28:239-240. https://doi.org/10.1016/j. tim.2020.02.001.https://www.sciencedirect.com/science/article/ pii/S0966842X20300251

Yan R, Zhang Y, Li Y, Xia L, Guo Y, Zhou Q (2020) Structural basis for the recognition of SARS-CoV-2 by full-length human ACE2. Science 367(6485):1444-1448. https://doi.org/10.1126/scien ce.abb2762

Zhou C, Xiao H (2020) COVID-19: challenges to GIS with big data. Geogr Sustain 1(1):77-87. https://doi.org/10.1016/j.geosu s.2020.03.005

Zhou D, Dai SM, Tong Q (2020) COVID-19: a recommendation to examine the effect of hydroxychloroquine in preventing infection and progression. J Antimicrob Chemother. https://doi. org/10.1093/jac/dkaa114

Zhou P, Yang X, Wang X et al (2020) A pneumonia outbreak associated with a new coronavirus of probable bat origin. Nature 579:270-273. https://doi.org/10.1038/s41586-020-2012-7

Publisher's Note Springer Nature remains neutral with regard to jurisdictional claims in published maps and institutional affiliations.

\section{Affiliation}

\section{Walter Leal Filho ${ }^{1,2} \cdot$ Anabela Marisa Azul ${ }^{3} \cdot$ Tony Wall $^{4,5} \cdot$ Claudio R. P. Vasconcelos $^{6,7} \cdot$ Amanda Lange Salvia $^{8}$. Arminda do Paço ${ }^{9} \cdot K$ Kalterina Shulla ${ }^{10}$. Vanessa Levesque ${ }^{11} \cdot$ Federica Doni $^{12}$. Lorena Alvarez-Castañón $^{13}$. Claudia Mac-lean ${ }^{14}$. Lucas Veiga Avila ${ }^{15}$. Luana Inês Damke ${ }^{16}$. Paula Castro ${ }^{17}$. Ulisses M. Azeiteiro ${ }^{18}$. Bárbara Fritzen $^{8}$ (D) Paula Ferreira ${ }^{19} \cdot$ Fernanda Frankenberger ${ }^{20,21}$}

Walter Leal Filho

walter.leal2@haw-hamburg.de

Anabela Marisa Azul

amjrazul@ci.uc.pt

Tony Wall

t.wall@chester.ac.uk

Claudio R. P. Vasconcelos

claudioruy@yahoo.com

Amanda Lange Salvia

amanda.langesalvia@haw-hamburg.de

Arminda do Paço

apaco@ubi.pt

Kalterina Shulla

kalterina@yahoo.co.uk

Vanessa Levesque

vanessa.r.levesque@maine.edu
Federica Doni

federica.doni@unimib.it

Lorena Alvarez-Castañón

lc.alvarez@ugto.mx

Claudia Mac-lean

clau.maclean.b@gmail.com

Lucas Veiga Avila

lucas.avila@ufsm.br

Luana Inês Damke

luanadamke@hotmail.com

Paula Castro

pcocastro@gmail.com

Ulisses M. Azeiteiro

ulisses@ua.pt

Paula Ferreira

paulaf@dps.uminho.pt 
Fernanda Frankenberger

ferfrank1@ hotmail.com

1 European School of Sustainability Science and Research, Hamburg University of Applied Sciences, Ulmenliet 20, 21033 Hamburg, Germany

2 Department of Natural Sciences, Manchester Metropolitan University, Chester Street, Manchester M11 5GD, UK

3 CNC-Center for Neuroscience and Cell Biology, Rua Larga, University of Coimbra, 3004-504 Coimbra, Portugal

4 IIIUC-Institute for Interdisciplinary Research, University of Coimbra, 3030-789 Coimbra, Portugal

5 International Centre for Thriving, University of Chester, Chester, UK

6 Laboratory of Sustainability Engineering and Consumption, Federal University of Paraíba, João Pessoa, PB, Brazil

7 Algoritmi Research Centre, School of Engineering, University of Minho, 4800-058 Guimarães, Portugal

8 University of Passo Fundo, BR 285, São José, Passo Fundo, Rio Grande do Sul 99052-900, Brazil

9 Universidade da Beira Interior, Núcleo de Estudos Em Ciências Empresariais (NECE-UBI), Rua Marquês d'Ávila e Bolama, 6201-001 Covilhã, Portugal

10 Center for Development Research (ZEF), University of Bonn, Genscherallee 3, 53113 Bonn, Germany

11 Department of Environmental Science and Policy, University of Southern Maine, Gorham, ME, USA
12 Department of Business and Law, University of Milano-Bicocca, Via Bicocca degli Arcimboldi 8, 20126 Milan, Italy

13 Departament of Social Studies, University of Guanajuato, Guanajuato, Mexico

14 Vice-Rectory of Academic Affairs-VRAC , University of Magallanes-UMAG, Punta Arenas, Región de Magallanes Y Antártica Chilena, Chile

15 Post-Graduation in Production Engineering PPGEP and Post-Graduation in Accounting Sciences-PPGCC, Federal University of Santa Maria-UFSM, Cachoeira Do Sul, RS, Brazil

16 Federal University of Santa Maria, Av. Roraima, 1000-Camobi, Santa Maria, RS 97105-900, Brazil

17 Department of Life Sciences, Centre for Functional Ecology, Science for People and the Planet, University of Coimbra, Calçada Martim de Freitas, 3000-456 Coimbra, Portugal

18 Department of Biology and cESAM, Centre for Environmental and Marine Studies, University of Aveiro, 3810-193 Aveiro, Portugal

19 ALGORITMI Research Center, University of Minho, Guimarães, Portugal

20 Pontifical Catholic University of Paraná-PUCPR, R. Imac. Conceição 1155, Curitiba, PR 80215-901, Brazil

21 Positivo University-UP, R. Prof. Pedro Viriato Parigot de Souza 5300, Curitiba, PR 81280-330, Brazil 